\title{
İlkokul Öğrencilerinin Kütüphane Algılarını Belirlemek İçin Çizimlerden Yararlanma: Bilkent Erzurum İlköğretim Okulu Örneği*
}

\section{Using Drawings to Determine Library Perceptions of Primary School Students: Bilkent Erzurum Primary School Example}

\author{
Şeyda Çelebi Erdoğan ${ }^{1}$ (D), Malik Yılmaz ${ }^{2}$ (1)
}

*Bu çalıșma; 2019 yılında Atatürk Üniversitesi Sosyal Bilimler Enstitüsünde Şeyda Çelebi Erdoğan tarafindan tamamlanan "Illkokul Öğrencilerinin Kütüphaneye Karșı Tutumlarının ve Algılarının İncelenmesi: Bilkent Erzurum İlkokulu Örneği” başlıklı yüksek lisans tezine dayanarak hazırlanmıștır.

${ }^{1}$ Prof. Dr. İhsan Doğramacı Vakfı Özel Bilkent Erzurum Laboratuvar Okulları, Erzurum, Türkiye

${ }^{2}$ Dr. Öğr. Üyesi, Atatürk Üniversitesi, Edebiyat Fakültesi, Bilgi ve Belge Yönetimi Bölümü,

Erzurum, Türkiye

ORCID: S.C.E. 0000-0002-2614-1376; M.Y. 0000-0002-3217-9776

Sorumlu yazar/Corresponding author: Seyda Celebi Erdoğan,

İhsan Doğramacı Vakfı Özel Bilkent Erzurum Laboratuvar Okulları, Erzurum, Türkiye

E-posta: celebiseyda@gmail.com

Bașvuru/Submitted: 21.05 .2021

Revizyon Talebi/Revision Requested: 04.06.2021 Kabul/Accepted: 13.06 .2021

Online Yayın/Published Online: 25.06.2021

Atıf/Citation: Celebi Erdoğan, Ș. ve Yılmaz, M. (2021). İlkokul öğrencilerinin resimsel çizimlerinde ve resimlerine yönelik yorumlarında kütüphane algisi: Bilkent Erzurum İlkokulu örneği. Bilgi ve Belge Araştırmaları Dergisi, 15, 73-94. http://doi.org/10.26650/bba.2021.15.04
ÖZ

Kütüphane, sahip olduğu basılı ve elektronik bilgi kaynakları ve sunduğu bilgi hizmetleri ile her yaştan bireylerin bilgilenmesine ve öğrenmesine katkı sağlayan kurumdur. Kütüphane kullanma ve okuma alışkanlığı, çocuk yaşlarda kazanılan ve sonraki yaşamda sürdürülen bir davranıştır. Bu çalışmanın amacı, ilkokul düzeyindeki öğrencilerin kütüphaneye karşı tutumlarını ve algılarını çizdikleri resimler ve bunlara yönelik ifadeleri ve yorumlarıyla ortaya koymaktır. Veriler, amaçlı örnekleme yöntemi kullanılarak, Erzurum ilindeki Bilkent Erzurum İlkokulu'nda öğrenim görmekte olan şema öncesi aşama ve şematik aşama döneminde olan 6-10 yaş arasındaki 57 öğrenciden çizme ve yazma tekniği ile elde edilmiştir. Çocukların çizdikleri resimler ve resimlere ilişkin açıklamaları incelenerek yorumlanmıştır. Araştırmada nitel araştırma desenlerinden olgubilim ve sanat temelli araștırma desenleri kullanılmıștır. Araştırma sonucunda öğrencilerin çizdikleri resimlerinde ve yazılı anlatımlarında kütüphaneye dair çoğu obje ve temaya yer verdikleri ve kütüphaneye karşı olumlu bir algılarının, düşüncelerinin ve deneyimlerinin olduğu saptanmıștır.

Anahtar kelimeler: Kütüphane algısı, İlköğretim öğrencileri, Çizim, Resim yorumlama, Okul kütüphaneleri

\section{ABSTRACT}

The library, with its printed and electronic resources and information services, is an institution that contributes to the information and learning of individuals of all ages. The habits of reading and using the library are acquired in childhood and continued in later life. The aim of this study is to reveal the attitudes and perceptions of primary school students toward the library through the pictures they draw and their expressions and comments. The data were collected through the purposeful sampling method by observing drawing and writing from 57 students aged 6-10 who were in the pre-schematic and schematic stage, at Bilkent Erzurum Primary School in Erzurum, Turkey. The children's pictures and explanations were analyzed and interpreted. Phenomenology and qualitative art-based research designs were used in the research. We observed that the students included most objects and themes about the library in their drawings and written expressions and that they had positive perceptions, thoughts, and experiences toward the library.

Keywords: Library perception, Primary school students, Drawing, Painting interpretation, School libraries 


\section{EXTENDED ABSTRACT}

Library habits can be explained as the individual's use of the library for different purposes and at certain frequencies. The habits around reading and using the library contributes to an individual's language and effective communication skills, development of intelligence, success in education, critical thinking ability, and a social personality. For the child, drawing can sometimes replace language. Children sometimes try to explain things that they cannot express verbally by drawing. Imagination has a significant effect on children's painting drawings. The child approaches the outside world, events, and objects without being bound by the rule of logic. Also, drawing is a language for children in which they use different symbols and shapes. While children may draw some objects to be smaller or larger than they are, they can also draw some things by likening them to different metaphors such as the star, the moon, and the sun. A child's metaphors can provide very important information in perceiving the library and the librarian. In this study, to reveal the children's perceptions about the library, the drawings they have drawn and interpreted were used, and, accordingly, there was an attempt to discern how students reflect the library habits and library perception by drawing them.

In the study, students' tendency to read books, their library perceptions and usage habits, and their attitudes and tendencies in this direction were determined and evaluated with their drawings and expressions. The main purpose of the study is to reveal the attitudes and perceptions of primary school students toward the library, books, and reading through their comments and original drawings. The study was carried out by using qualitative research through art-based research techniques. In this study, primary school students' perceptions of the library and, accordingly, books and reading, were examined based on their own pictures and their overall comments on the pictures. The participants in the study are primary school first, second, third, and fourth grade students. Primary school students were chosen as the source of this data because they were most likely to express their feelings, thoughts, and perceptions about any subject through pictorial drawings.

The research included 57 students between the ages of 6-10 from four different classes at Bilkent Erzurum Primary School in Erzurum, Turkey. The data were collected through an art-based qualitative research method (in the context of students drawing and interpreting their perceptions of the library). To obtain the necessary data for the study, the students were asked, "What comes to mind when you say library?" They were asked to spend 40 minutes, or one class, period, drawing their perceptions of the library using crayons and A4 size paper. After the drawings were completed, the students were asked to interpret them. These comments were recorded and used to determine the perception of the library in the drawings of the students during the analysis of the data in the study. The data obtained from the students' pictorial expressions and their written expressions based on their drawings were evaluated and interpreted through document analysis. 
This analysis showed that the students' drawings and comments were generally related to the library. Most of the students reflected the library spatially in their drawings. Generally speaking, students gave more space to books, shelves, and librarian items among the subtitles of the library theme. Under the "library material" theme, the first thing that comes to mind for all $(100 \%)$ of the students when the library is mentioned is books. Second, $50(88 \%)$ of the students included a shelf, and third, $32(56 \%)$ of the students included library staff. Three $(5 \%)$ students mentioned the library week activities under the main theme of "library activities." The drawings and concepts related to the library perception that emerged in the pictorial expressions are proof that students have perceptions and knowledge of the library, but students, think of the library more in terms of place and building than its function. However, it has been concluded that the first thing that comes to students' minds when the library is mentioned is the book. 


\section{GíRIŞ}

Kütüphaneler bireylerin bilgilenmesine, öğrenmesine, düşünmesine, anlamasına ve yorumlama becerileri elde etmesine katkı sağlamasından ötürü insan hayatında önemli bir yere sahiptir. Bu doğrultuda, bireylerin daha dar anlamıyla öğrencilerin erken yaşlarda kütüphane ve kitap ile tanışmaları ve kaynaşmaları, kütüphanenin ve kitabın önemini kavramalarına, ayrıca okuyarak ve öğrenerek elde edecekleri bilgilenmenin ve başarıların farkına varmalarına neden olacaktır. Eğitimi ve ders müfredatını destekleyecek şekilde oluşturulan okul ve halk kütüphaneleri, toplumun bir parçası olan öğrencilerin başarısında önemli bir yer tutar. Kütüphanede sunulan hizmetlerin etkin ve kütüphanenin bilgi kaynakları açısından zengin olması, kuşkusuz öğrenci başarısını yükseltecektir. Bu bağlamda öğrenci gelişiminde ve başarısında kütüphaneler sahip olduğu bilgi kaynakları ve sundukları bilgi hizmetleri ile önemli katkılar sunar.

İnsanoğlu doğası gereği çevresini değiştirmek, hayatta kalmak ve merakını gidermek için sürekli yeni ve farklı bilgiye ihtiyaç duyar. Bilgi, deneyimler ve uygulamalarla elde edilebildiği gibi basılı ve elektronik bilgi kaynaklarından da elde edilebilmektedir. Bu açıdan insan temelde bilgi ihtiyacını gidermek ve yeni şeyler öğrenmek için bilgi kaynaklarına sahip ve bu kaynakları çeşitli bilgi hizmetleri ile kullanıcıya sunan kütüphaneleri de kullanmaktadır. Çeşitli türden kütüphanelerin temel amacı, öğrenme ve bilgilenme amaciyla kütüphaneye gelen her yaştan bireyin bilgi ihtiyacını karşılamak, bireysel ve toplumsal kalkınmayı ve gelişmeyi sağlamaktır. Öğrencilerin kütüphaneye karşı tutumları ve algıları kütüphaneyi kullanırken oluşur. Çocukların erken yaşta kütüphane ile tanışmaları ve kütüphaneyi etkin şekilde kullanmaları, onlarda kütüphane ve kitaba karşı olumlu bir algı oluşturacaktır. Bu eylem, çocukların kitabı ve kütüphaneyi sevmesini kolaylaştıracak ve onlarda kütüphane kullanımının ve okuma alışkanlığının gelişmesini sağlayacaktır. Kütüphanenin, öğrenci başarısındaki önemini kavrayan okullar, her şeyden önce kullanıcı ve/veya öğrenci profiline uygun etkin bir kütüphane oluşturmayı ve öğrencilere kütüphane alışkanlığı kazandırarak, onlarda bu kavrama yönelik olumlu algı yaratmayı amaçlamaktadır.

Türkiye' de kütüphanelerin öneminin halen yeterince kavranamadığı, çoğu ilk ve ortaöğretim okullarında nitelikli bir okul kütüphanesinin olmadığı bilinmektedir. Bazı okulların kütüphanesi mevcuttur, ancak bu kütüphanelerin ne yazık ki büyük bir kısmı okul kütüphanesi standartlarını karşılayamamaktadır. Okul kütüphaneleri personel sorunu, dermenin kısıtlılığ 1 ve fiziki açıdan kütüphane ortamının uygunsuz oluşu gibi olumsuz nedenlerden ötürü standartların oldukça uzağında kalmaktadır (Önal ve Alaca, 2015, s. 106). Türkiye'de kütüphaneye verilen önem hiç kuşkusuz devlet ve özel okullarda çok farklıdır. Daha önce yapılıış olan çalışmalarda, kütüphanenin öneminin devlet okullarına göre özel okullarda daha iyi kavrandığı ve bu okullarda genellikle kütüphanenin ve kütüphanecinin olduğu saptanmıştır (Cevizbaş, 2003, s. 396; Y1lmaz, 2015, s. 259-284). 
Genel olarak bakıldığında eğer bir okulda kütüphane ve kütüphaneci mevcut ise kütüphane kullanma alışkanlığı edinmedeki sorumluluk kütüphaneciyi de kapsamaktadır. Öğrencilerin, kütüphane ve okuma alışkanlığı edinmelerinde kütüphaneci ve öğretmen ilişkisi de çok önemlidir. Öğretmenler kütüphaneyi sıklıkla kullandıklarında ve öğrencileri kütüphaneye yönlendirerek onlara rol model olduklarında, öğrencilerde kütüphane algısı ve alışkanlığı oluşacak ve kütüphaneci, öğretmen katkısıyla çocuğa kütüphane kullanma alışkanlığı ile birlikte kitap okuma sevgisi aşılanabilecektir. Kitap ve kütüphane sevgisini kazanan öğrenci için de kütüphane, vazgeçilmez olacak ve kütüphane kullanımı bir alışkanlık haline gelecektir.

Bireylerde kütüphane ve kitap okuma alışkanlığının bir ihtiyaç olarak algılanması önemlidir. Bireyde kitap okumanın sürekli ve düzenli olarak gerçekleştirilmesi okuma alışkanlığı; kütüphaneden farklı amaçlarla ve belirli sıklıklarda yararlanması ise kütüphane kullanma alışkanlığı olarak tanımlanmaktadır. Okuma ve kütüphane kullanma alışkanlığı bireyin, dil ve etkili iletişim becerisi, zekâ gelişimi, eğitimde başarı, eleştirel düşünme yeteneği ve sosyal bir kişilik kazanmasına katkıda bulunmaktadır. Okuma eyleminin çoğunlukla, genel kültür düzeyini artırma, mesleki bilgileri güncel tutma, merak edilen konularda bilgi edinme ve zevk amaçlarıyla gerçekleştirildiği söylenebilir. Okuma ve kütüphane kullanma alışkanlıklarının bireylere kazandırılmasında temel rol, bu konudaki ebeveyn duyarlığının yetersiz kaldığ toplumlarda, öğretmenlere düşmektedir (Yılmaz, 2002, s. 442).

Çocuk için resim, zaman zaman dilin yerine geçebilmektedir. Çocuklar sözel olarak ifade edemedikleri duygularını ve düşüncelerini bazen resim çizerek anlatmaya çalışırlar. Resim çizmelerinde hayal gücünün önemli bir etkisi vardır. Çocuk, dış dünyaya, olaylara ve nesnelere mantık kuralına bağlı kalmaksızın yaklaşır; kendi dünyasının gerçekleriyle bir anlatıma yönelir (Okyay ve Fazıloğlu, 2009, s. 2). Diğer yandan resim, çocuklar için farklı sembol ve şekilleri kullandıkları bir iletişim aracıdır. Çocuklar resimlerinde bazı nesneleri veya eşyaları olduğundan büyük ya da daha küçük çizebileceği gibi bazı şeyleri de yıldız, ay, güneş gibi farklı metaforlara benzeterek çizebilmektedirler. Bu bağlamda çocukların benzettikleri metaforlar, kütüphaneyi ve kütüphaneciyi algılamada oldukça önemli bilgiler verecektir (Aykaç, 2012, s. 301). Çalışmada, çocukların kütüphaneye yönelik algılarını ve düşüncelerini ortaya koymak amacı ile çizmiş ve yorumlamış oldukları resimlerinden yararlanılmış, bu doğrultuda öğrencilerin, kütüphane algılarını çizerek nasıl yansıttıkları ortaya konulmaya çalışılmıştır.

\section{Araştırmanın Amacı ve Soruları}

Çalışmada, öğrencilerin kitap okuma, kütüphane algıları ve kullanma alışkanlıkları ve bu yöndeki tutum ve eğilimleri çizdikleri resimler ve anlatımlarıyla belirlenerek değerlendirilmiştir. Çalışmanın temel amacı, ilkokul düzeyindeki öğrencilerin kütüphaneye, kitaba ve okumaya karşı tutumlarını ve algılarını çizdikleri resimler ve bunlara yönelik ifadeleri ve/veya yorumları aracılığıyla ortaya koymaktır. Araştırmada temelde aşağıdaki soruya yanıt aranmıştır: 
6-10 yaş aralığındaki ilkokul öğrencilerinin resimlerinde ve resimlere ilişkin açıklamalarında/ yorumlarında kütüphaneye ve kitaba ilişkin algıları ve düşünceleri nasıldır?

\section{Yöntem}

Resim yapmak, çocuğun alg1 ve gözlemleriyle birlikte hayal dünyasını, duygularını ve hissettiklerini yansıtması açısından samimi bir ifade biçimidir. Çocuklar, dış dünyayla ilgili algılarını sergileyerek, iç dünyalarıyla ilgili birçok ipucu verirler. Çocukların olayları, insanları ve etraflarındaki nesneleri nasıl algıladıklarını açıklamalarının en iyi yollarından biri de resim çizmeleridir. Çocuklar çizdikleri resimlerle kendi düşüncelerini organize ederek ve yorumlayarak dış dünyayı nasıl algıladıklarını ortaya koyarlar (Ersoy ve Türkkan, 2009, s. 57).

Çalışmada nitel araştırma desenlerinden olgubilim (phenomenology) ve sanat temelli araştırma (art based inquiry) desenleri kullanılmıştır. Olgubilim yaklaşımında, bireylerin bir olgu (bireyin deneyimlediği her şey) ile ilgili deneyimlerinin özünü, bireyin doğrudan kendisinden derinlemesine elde etmek amaçlanmaktadır (Creswell, 2007, s. 58). Sanat temelli araştırma tekniği, bilimsel araştırmalarda sanat ve araştırmanın bir arada olduğu bir tekniktir. Bu teknikle öğrencilerin sanatsal anlatımları yoluyla çeşitli durumlara ilişkin algıları ve bakış açıları, kendi izlenimlerinden yola çıkarak ortaya konulmaya çalışılmaktadır. Çalışmalarda resimleri ve resimsel anlatımlara dayalı verileri kullanmak özellikle ilköğretim düzeyinde öğrenci merkezli bir süreçtir ve aynı zamanda yine öğrenci merkezli bir değerlendirme aracıdır (Erişti ve Belet, 2010, s. 248).

Bu araştırmada ilköğretim öğrencilerinin kütüphaneye ve kitaba yönelik algıları, çizmiş oldukları resimler ve resimlere ilişkin görüşlerine ve/veya yorumlarına dayalı olarak incelenmiştir. Sanat temelli araştırma, sanat ve araştırmanın birleştiği akademik bağlamda doğmuştur. Büyüyen bir ilgi alanı olan, sanat temelli araştırma, araştırma pratiğinin her aşamasında etkili bir yaklaşım haline gelmiştir. Sanat temelli araştırma ve uygulama arasındaki ilişki, araştırma olgusuna yeni ve sıra dışı yaklaşımlar için verimli bir zemin sağlamaktadır. Sanatçılar ve sosyal bilimciler, araştırmalarında özgün sonuçlara ulaşmalarını mümkün kılan sanat temelli araştırmaların çeşitli yaklaşımlarını benimsemişlerdir (Erişti 2015, s. 383).

\section{3. Çalışma Grubu ve Veri Toplama}

Araştırmanın katılımcılarını ilköğretim 1, 2, 3, ve 4. sınıf öğrencileri oluşturmaktadır. Çalışma ile ilgili verilerin elde edilmesinde ilköğretim öğrencilerinin seçilmesinin nedeni, bu öğrencilerin herhangi bir konu hakkındaki duygu, düşünce ve algılarını resimsel çizimler yolu ile anlatmalarının nitelikli veriler sunan bir yöntem olarak düşünülmesidir. Araştırma, Erzurum il merkezinde yer alan Bilkent Erzurum İlkokulu'nda öğrenim gören söz konusu sınıflara ait yaşları 6-10 aralığında olan 57 öğrenciyi kapsamaktadır. Araştırmanın verileri, 2018 yılı Aralık ayında toplanmıştır. Çalışmadaki katılımcı sayısı $(\mathrm{n}=57)$ nitel araştırmalar 
bağlamında değerlendirildiğinde, ortaya çıkarılmak istenen olgu hakkında derinlemesine bilgi elde edilmesine imkân sağlaması açısından yeterli düzeydedir (Padgett, 2008, s. 56).

Tablo 1. Öğrencilerin demografik bilgileri

\begin{tabular}{|l|c|c|c|c|c|c|c|c|}
\hline Öğrencilerin Sınıfi & \multicolumn{2}{|c|}{1} & \multicolumn{2}{|c|}{2} & \multicolumn{2}{c|}{3} & \multicolumn{2}{c|}{$\mathbf{4}$} \\
\hline Öğrenci Cinsiyeti & Kız & Erkek & Kız & Erkek & Kız & Erkek & Kız & Erkek \\
\hline Öğrenci Sayıs1 & 12 & 2 & 8 & 9 & 9 & 6 & 7 & 4 \\
\hline Toplam Öğrenci & \multicolumn{9}{|c|}{57} \\
\hline
\end{tabular}

Tablo 1'de görüldüğü gibi araştırmanın katılımcılarının, 14'ü 1. sınıf, 17'si 2. sınıf, 15'i 3. sınıf ve 11'i de 4. sınıftır. 1. sınıf öğrencilerinin 12'si kız, 2'si erkek; 2. sınıf öğrencilerinin 8'i kı, 9'u erkek; 3. sınıf öğrencilerinin 9'u kız, 6'sı erkek; 4. sınıf öğrencilerinin ise 7'si kız, 4'ü erkektir. Öğrencilerin 36'sı kız, 21'i erkektir. Dolayısıyla araştırmaya dâhil olan toplam öğrenci sayısı 57'dir. Şematik öncesi aşama ${ }^{1}$ ve şematik aşama ${ }^{2}$ kapsamında yer alan öğrenciler dört farklı sınıfta eğitim almaktadır. Çalışma grubunun belirlenmesinde nitel araştırma yaklaşımlarından amaçlı örnekleme yöntemlerinden kolay ulaşılabilir durum örneklemesi kullanılmıştır. Nitel araştırmalarda temel yaklaşım, araştırmacının problem veya araştırma sorusunu en iyi biçimde anlamasına yardımcı olacak katılımcıların veya belgeler ya da görsel materyaller gibi diğer alanların/konuların amaçlı olarak seçilmesidir (Creswell 2014, s. 189). Veriler, nitel araştırma yöntemlerinden, sanat temelli araştırma tekniği aracılığıyla, öğrencilerin kütüphaneye ilişkin algılarını çizmeleri ve yorumlamaları bağlamında toplanmıştır. Öğrenciler, üçerli ve dörderli gruplar halinde oturtulmuştur. Çalışma için gerekli olan verilerin elde edilmesi amaciyla öğrencilere, "Kütüphane denilince aklınıza ne geliyor?” sorusu yöneltilmiş, boya kalemi ve A4 boyutunda kâğıt verilerek, yaklaşık 40 dakika boyunca kütüphane kavramını zihinlerinde nasıl canlandırdıklarını kâğıda çizmeleri ve çizimlerini yorumlamaları istenmiştir. Daha sonra her öğrencinin kendi resmine ait yorumları not edilmiş, çizdikleri resimlerle birlikte yorumlar araştırmada verilerin analizi sürecinde öğrencilerin kütüphane algısının belirlenmesinde kullanılmıştır. Araştırma kapsamında yer alan Bilkent Erzurum İlkokulu'nda bir kütüphane ile bu kütüphaneden sorumlu Bilgi ve Belge Yönetimi mezunu kütüphaneci mevcuttur.

1 Şematik öncesi aşama (The pre-schematic stage): Şematik öncesi aşama, çocuğun çevresindeki nesneler için ilk temsili sembollerini ürettiği aşamadır. Bu semboller daireler, kareler ve çizgilerle oluşturulur. Semboller sık sık değişir. Resimlerde yüzen bir düzen vardır ve çizim yapılırken kâğıt defalarca döndürülebilir. Daha sonra semboller yatay olarak düzenlenebilir. Şematik öncesi aşama, çocuğun ilk sembollerini çizdiği ancak henüz 'şema' geliştirmediği genelde 3-7 yaş arası aşamayı ifade eder (Salome ve Moore, 2021).

2 Şematik aşama (The schematic stage): Bu aşamanın temel özellikleri, tanıdık nesneler için sembollerin tekrarlanması ve taban çizgisinin kullanılmasıdır. Bu aşamada çocuk tarafından kullanılan başlıca organizasyon araçları çoklu temel çizgilerdir. Röntgen veya şeffaf görünümler, üstten görünümler, yandan görünümler veya yükseltilmiş taban çizgileri ve betimlenen özne, tek bir temel çizgiden değişiklik talep ettiğinden, artan sıklıkta kullanılır. Resimler daha karmaşık hale gelir, fakat yine de şema ile birlikte tek taban çizgileri, çoklu taban çizgileri ve katlanır görünümler kullanılır. Genelde çocuklar bu aşamaya 6-11 yaşları arasında ulaşırlar (Salome ve Moore, 2001). 


\section{Bulgular}

Öğrencilerin çizdikleri resimlerinden ve resimlerine dayalı yazılı ifadelerinden elde edilen veriler doküman incelemesi yoluyla değerlendirilerek yorumlanmıştır. Yapılan analiz sonucunda öğrencilerin resimsel anlatımlarında ve bu anlatımlarına dayalı yazı ve yorumlarından ortaya çıkan temalar; "kütüphane materyali, kütüphane sistemi, kütüphane etkinlikleri ve kütüphane personeli" şeklinde dört ana başlık altında toplanmıştır. Araştırmada elde edilen bulgular "öğrencilerin resimlerindeki kütüphane temaları" ana teması altında toplanmıştır. Öğrenci resimlerinin analiz edilmesiyle belirlenen temaların tümünü kapsayan bir tablo oluşturulmuştur ve verilerin yüzdelere göre dağılımı belirlenmiş̧ir. Oluş̧urulan tabloda kütüphane öğesi olarak nitelendirilen tema ve bu temaya ait alt başlıklar yer almıştır. Söz konusu dört başlıktan oluşan ana temalar ve alt temalar Tablo 2'de gösterilmiştir. Tabloda yer alan K kızı, E erkeği T ise toplamı ifade etmektedir.

Tablo 2. Öğrencilerin resimsel anlatımları ve resme dayalı yorumlarıyla ortaya çıkan kütüphane temaları

\begin{tabular}{|c|c|c|c|c|c|c|c|c|c|c|c|c|c|c|c|c|}
\hline \multirow{3}{*}{$\begin{array}{l}\text { Öğrencilerin Sınıfı } \\
\text { Öğrencilerin Cinsiyeti }\end{array}$} & \multicolumn{3}{|c|}{1} & \multicolumn{3}{|c|}{2} & \multicolumn{3}{|c|}{3} & \multicolumn{3}{|c|}{4} & \multicolumn{3}{|c|}{$\begin{array}{c}\text { Genel } \\
\text { Toplam }\end{array}$} & \multirow[t]{2}{*}{$\begin{array}{c}\text { Toplam } \\
\%\end{array}$} \\
\hline & $\mathbf{K}$ & $\mathbf{E}$ & $\mathbf{T}$ & $\mathbf{K}$ & $\mathbf{E}$ & $\mathbf{T}$ & $\mathbf{K}$ & $\mathbf{E}$ & $\mathbf{T}$ & $\mathbf{K}$ & $\mathbf{E}$ & $\mathbf{T}$ & $\mathbf{K}$ & $\mathbf{E}$ & $\mathbf{T}$ & \\
\hline & \multicolumn{16}{|c|}{$\mathbf{F}$} \\
\hline Öğrencilerin Sayısı & 12 & 2 & 14 & 8 & 9 & 17 & 9 & 6 & 15 & 7 & 4 & 11 & 36 & 21 & 57 & \\
\hline Kütüphane Materyali & $\mathrm{K}$ & $\mathrm{E}$ & $\mathrm{T}$ & K & $\mathrm{E}$ & $\mathrm{T}$ & $\mathrm{K}$ & $\mathrm{E}$ & $\mathrm{T}$ & $\mathrm{K}$ & $\mathrm{E}$ & $\mathrm{T}$ & $\mathrm{K}$ & $\mathrm{E}$ & $\mathrm{T}$ & \\
\hline Kitap & 12 & 2 & 14 & 8 & 9 & 17 & 9 & 6 & 15 & 7 & 4 & 11 & 36 & 21 & 57 & 100 \\
\hline Raf & 12 & 2 & 14 & 7 & 8 & 15 & 6 & 6 & 12 & 6 & 3 & 9 & 31 & 19 & 50 & 87.71 \\
\hline Oyuncak & 2 & 1 & 3 & - & 3 & 3 & 1 & - & 1 & 4 & - & 4 & 7 & 4 & 11 & 19.29 \\
\hline Poster & 3 & 1 & 4 & 1 & 1 & 2 & 2 & 2 & 4 & 1 & 1 & 2 & 7 & 5 & 12 & 21.05 \\
\hline Minder & - & 1 & 1 & - & - & - & 3 & 1 & 4 & - & 2 & 2 & 3 & 4 & 7 & 12.28 \\
\hline Masa & 4 & 1 & 5 & 2 & 3 & 5 & 3 & 3 & 6 & 2 & 1 & 3 & 11 & 8 & 19 & 33.33 \\
\hline Sandalye & 1 & 1 & 2 & 2 & 1 & 3 & 2 & 2 & 4 & 2 & 1 & 3 & 7 & 5 & 12 & 21.05 \\
\hline Bilgisayar & 1 & - & 1 & - & 1 & 1 & - & - & - & 5 & 1 & 6 & 6 & 2 & 8 & 14.03 \\
\hline Kütüphane Sistemi & $\mathrm{K}$ & $\mathrm{E}$ & $\mathrm{T}$ & K & $\mathrm{E}$ & $\mathrm{T}$ & $\mathrm{K}$ & $\mathrm{E}$ & $\mathrm{T}$ & $\mathrm{K}$ & $\mathrm{E}$ & $\mathrm{T}$ & $\mathrm{K}$ & $\mathrm{E}$ & $\mathrm{T}$ & \\
\hline Sinıflama Sistemi & 2 & 2 & 4 & 3 & 2 & 5 & 1 & 3 & 4 & 3 & - & 3 & 9 & 7 & 16 & 28.07 \\
\hline Ödünç Verme Sistemi & - & - & - & 3 & 5 & 8 & 3 & 2 & 5 & 1 & 1 & 2 & 7 & 8 & 15 & 26.31 \\
\hline Kütüphane Kuralları & 6 & 6 & 12 & - & 1 & 1 & 4 & 4 & 8 & 1 & 1 & 2 & 11 & 12 & 23 & 40.35 \\
\hline $\begin{array}{l}\text { Kütüphane } \\
\text { Etkinlikleri }\end{array}$ & $\mathrm{K}$ & $\mathrm{E}$ & $\mathrm{T}$ & $\mathrm{K}$ & $\mathrm{E}$ & $\mathrm{T}$ & $\mathrm{K}$ & $\mathrm{E}$ & $\mathrm{T}$ & $\mathrm{K}$ & $\mathrm{E}$ & $\mathrm{T}$ & $\mathrm{K}$ & $\mathrm{E}$ & $\mathrm{T}$ & \\
\hline Kitap Okuma & 4 & - & 4 & 3 & 3 & 6 & 2 & 2 & 4 & 3 & 1 & 4 & 12 & 6 & 18 & 31.57 \\
\hline Kütüphane Dersi & 5 & 1 & 6 & - & 1 & 1 & 2 & 1 & 3 & - & - & - & 7 & 3 & 10 & 17.54 \\
\hline Kütüphane Haftası & - & - & - & 1 & 1 & 2 & 1 & 1 & 2 & - & - & - & 2 & 2 & 4 & 7.01 \\
\hline Kütüphane Personeli & $\mathrm{K}$ & $\mathrm{E}$ & $\mathrm{T}$ & $\mathrm{K}$ & $\mathrm{E}$ & $\mathrm{T}$ & $\mathrm{K}$ & $\mathrm{E}$ & $\mathrm{T}$ & $\mathrm{K}$ & $\mathrm{E}$ & $\mathrm{T}$ & $\mathrm{K}$ & $\mathrm{E}$ & $\mathrm{T}$ & \\
\hline Kütüphaneci & 7 & 1 & 8 & 8 & 7 & 15 & 4 & 1 & 5 & 4 & 4 & 8 & 23 & 13 & 36 & 63.15 \\
\hline
\end{tabular}


Tablo 2'de görüldüğü gibi öğrencilerin resimlerinde, resimsel anlatımlarına dayalı yazılı ifadelerinde ve yorumlarında, "Kütüphane Materyali” temasının altında yer alan öğelerden öğrencilerin 57'si (\%100) kitaba, 50'si (\%88) rafa, 11'i (\%19) oyuncağa, 12'si (\%21) postere, 7'si (\%12) mindere, 19'u (\%33) masaya, 12'si (\%21) sandalyeye ve 8'i de (\%14) bilgisayara yer vermiştir. Resimlerinde kütüphane ana teması olarak kütüphane materyaline yer veren öğrencilerin çoğunlukla kitap ve raf alt temasına da yer verdikleri görülmektedir. "Kütüphane Sistemi” temasının altında yer alan öğelerden öğrencilerin 16'sı (\%28) sınıflamaya 15'i (\%26) ödünç vermeye ve 23'ü (\%40) kütüphane kurallarına yer vermiştir. "Kütüphane Etkinlikleri” temasının altında yer alan öğelere, öğrencilerin 18'i (\%32) kitap okumaya, 10’u (\%18) kütüphaneci tarafından yapılan kütüphane derslerine ve 4'ü ise (\%7) kütüphane haftası etkinliklerine yer vermiştir. "Kütüphane Personeli” temasının altında yer alan kütüphaneci öğesine ise öğrencilerin 36’sı (\%63) yer vermiştir. Genel olarak bakıldığgnda öğrencilerin kütüphane temasına ait alt başlıklardan kitap, raf ve kütüphaneci öğelerine daha çok yer verdikleri görülmektedir. Araştırma kapsamında resme dayalı anlatımlarda ortaya çıkan kütüphane algısına ilişkin bu kavramlar, öğrencilerin kütüphaneye karşı algılarının, düşüncelerinin ve deneyimlerinin olduğunun kanıtıdır. Toplam resim çizdirilen öğrenci sayısı 57'dir. Çalışma kapsamında değerlendirilen ve yorumlanan öğrenci resim sayısı ise 16 'dır.

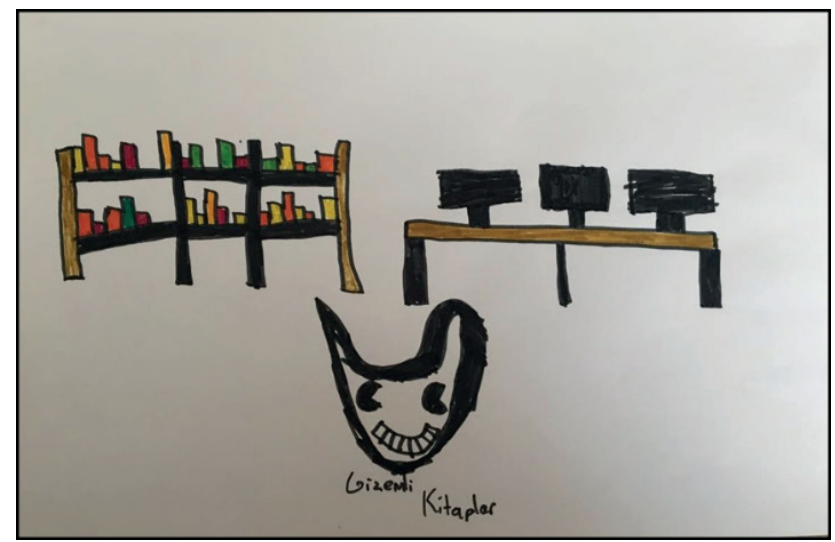

Resim 1. Emir (4)

4. sınıf öğrencisi olan Emir resme dayalı yorumunda 'Kütüphane denilince aklıma binlerce gizemli kitabın bulunduğu yer geliyor' demiştir. Gizemli kitapları çizerken de hayal gücüne dayalı olarak kitaplara gizem katmak amacıyla kendince farklı bir surat çizmiştir. Emir resimsel anlatımında ise, kütüphane öğesi olarak 'kütüphane materyali' ana temasının altında yer alan kitap, raf ve bilgisayara yer vermiştir (Resim 1). Resmine bakarak Emir'in kütüphane hakkında bilgi sahibi olduğu ve kütüphaneyi kitaplarla özdeşleştirdiği anlaşılmaktadır. 


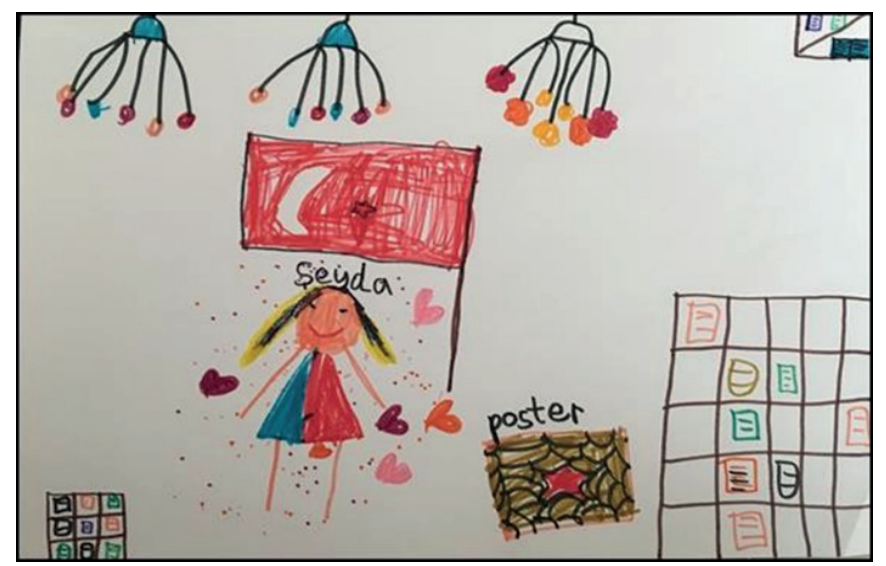

Resim 2. Elif (1)

Yaptığı resme dayalı yorumunda 1. sınıf öğrencisi Elif, "kütüphanede asılı olan Şeyda öğretmen (kütüphaneci) posterini ve süslerini çok sevdiğini” belirtmiş ve 'kütüphane materyali ve personeli' ana temalarını vurgulamıştır. Elif resimsel anlatımında, kütüphane öğesi olarak kitap, raf, poster ve kütüphaneciye yer verdiğini belirgin bir biçimde göstermiştir (Resim 2). Kütüphaneci öğesinin öne çıktığı bu resimde, bir okul kütüphanesinde mesleki ve akademik eğitim almış bir kütüphanecinin bulunmasının, kütüphaneci davranışının, ilgisinin ve kütüphanecinin doğru iletişim kurmasının ve sevilmesinin ne kadar önemli olduğu ortaya konulmuştur.

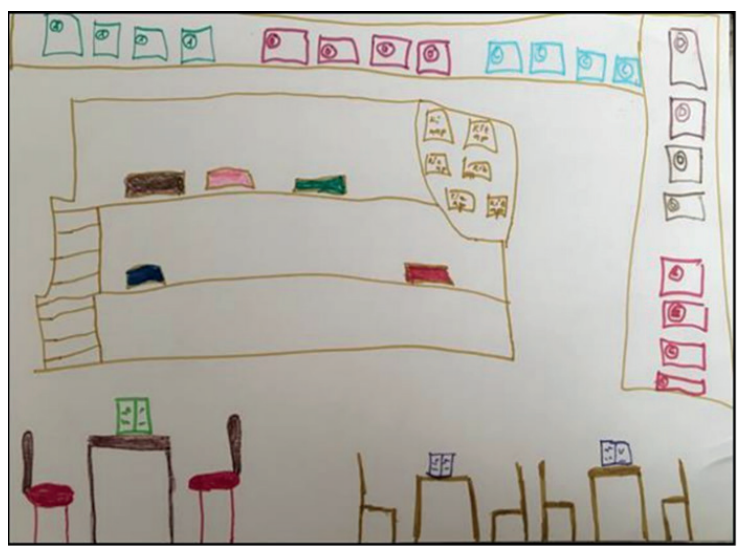

Resim 3. Ezgi (3)

Resimsel anlatımında kütüphaneyi mekânsal olarak gösteren 3. sınıf öğrencisi Ezgi, 'kütüphane materyali' ana temasının altında yer alan, kitap, raf, masa, sandalye ve minder öğelerine yer vererek, 'kütüphane denilince aklıma kitaplar, renkli renkli minderler, sandalye ve masa geliyor' yorumunda bulunmuştur. Ayrıca rafta çizdiği kitapları, alfabetik bir sıraya 
göre resmetmiştir. Kütüphanede rafa dizilen kitaplarda bir sistemin olduğunu vurgulayarak 'kütüphane sistemi' ana temasından sınıflama sistemini de yansıtmıştır (Resim 3). Bu resimde öne çıkan vurgu ise mekânsal algıdır. Bu durum kütüphane mekânının çocuk kullanıcılar için ne kadar önemli ve dikkat çekici olduğunu göstermektedir. Bu bağlamda kütüphane iç mekânının çocukların ilgisini çekecek ve onlara kütüphane alışkanlığı kazandıracak donatılarla teçhiz edilmesi göz önünde bulundurulması gereken bir husus olarak öne çıkmaktadır.

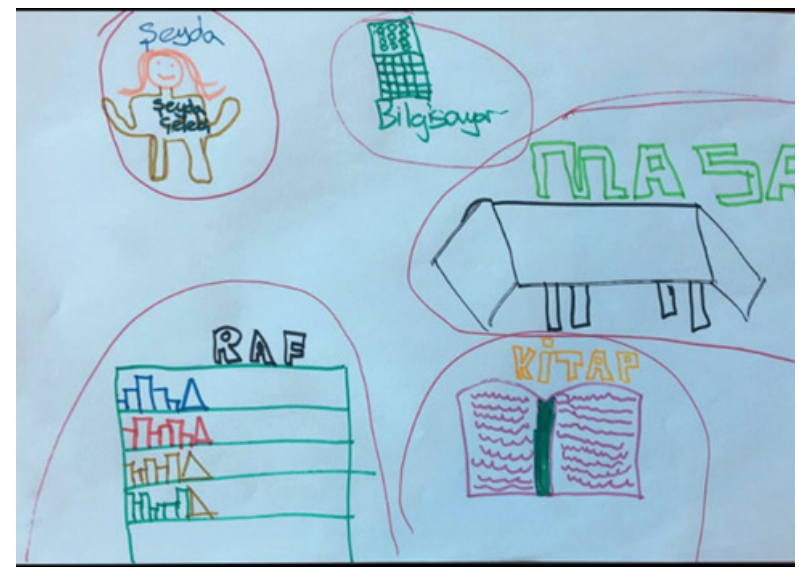

Resim 4. Yakup (2)

2. sınıf öğrencisi Yakup, yaptığı resme dayalı yorumunda; 'kütüphane denilince aklıma Şeyda öğretmen (kütüphaneci), bilgisayar, masa ve kitap dolu raflar geliyor' demiştir. Resimsel anlatımında ise 'kütüphane materyali ve personeli' ana temalarını vurgulayan Yakup, kütüphane öğesi olarak kitap, raf, masa, bilgisayar ve kütüphaneciye yer vermiştir (Resim 4). Resimde kütüphaneci vurgusunun öne çıkması, kütüphaneci algısının çocukların düşüncelerinde önemli bir yer işgal edebildiğini ve kütüphanecinin çocuklarda kütüphaneye karşı olumlu algılar oluşturabileceğini göstermektedir.

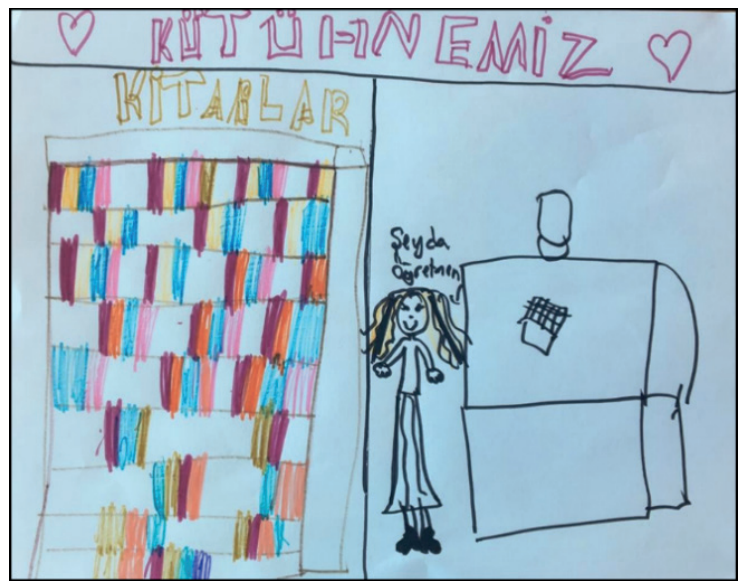

Resim 5. Aslı Bahar (2) 
Resimsel anlatımında kütüphane öğesi olarak 'kütüphane materyali, sistemi ve personeli' ana temalarının altında yer alan kitap, raf, ödünç verme masası, bilgisayar, ödünç verme sistemi ve kütüphaneciye (Şeyda öğretmen) yer veren 2. sınıf öğrencisi Aslı Bahar, resimsel anlatımına dayalı yorumunda da 'kitap ödünç almayı çok sevdiğini' vurgulamıştır (Resim 5). Resme dayalı olarak Aslı Bahar'ın kütüphanede en çok dikkat çektiği yerin danışma masası veya danışma hizmeti olduğu söylenebilir. Ayrıca kütüphaneciyi çizmesi, kütüphaneci, kitap ve kütüphaneyi özdeşleştirdiği ve bu bağlamda zihninde bir kütüphane algısının oluştuğu anlaşılmaktadır.

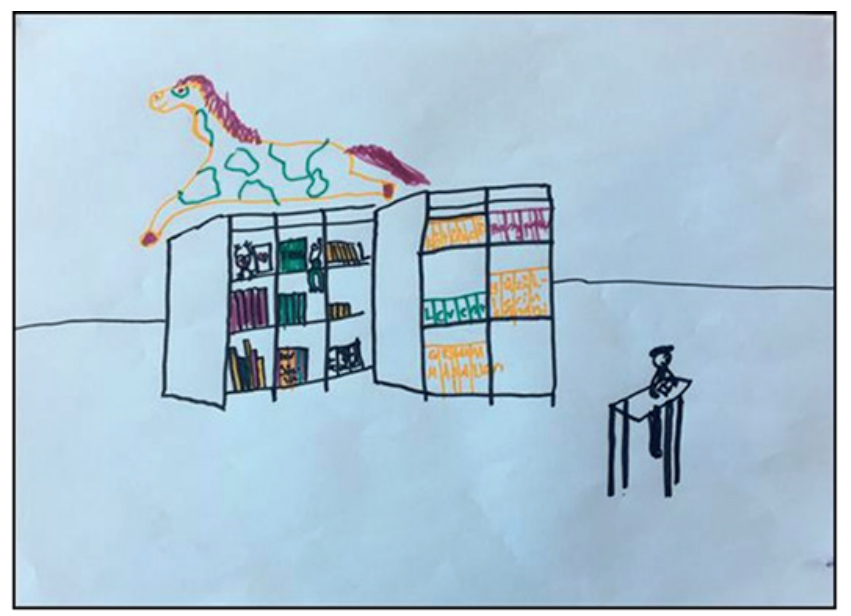

Resim 6. Nevra (4)

Yaptığı resme dayalı yorumunda 'kütüphane denilince aklıma bir sürü oyuncak, kitaplarla dolu raflar, sevdiğim kitap serileri geliyor' diyerek, 'kütüphane materyali ve etkinlikleri' ana temalarını vurgulayan 4. sınıf öğrencisi Nevra, resimsel anlatımında ise kütüphane öğesi olarak kitap, raf, oyuncak, masa, sandalye ve kütüphanede okuma eylemini çizmiştir. Okul kütüphanesinde bulunan büyük oyuncak atı çizen Nevra, onu çok sevdiğini de belirtmiştir. Ayrıca yaptığı resimde roman ve hikâyeleri aynı rafa yerleştirerek ve bazı kitapların üzerine sınıflama sistemiyle ilgili harfler çizerek 'kütüphane sistemi' ana temasının altında yer alan sınıflama sistemini de yansıtmıştır (Resim 6). Resme dayalı olarak Nevra'nın iyi ve dikkatli bir kütüphane kullanıcısı olduğu ayrıca temel kütüphane eğitimi aldığg söylenebilir. Bununla birlikte Nevra'nın çizdiği resimde kütüphane kavramına yönelik algısının, kütüphaneci tarafından şekillendirildiğini söylemek mümkündür. 


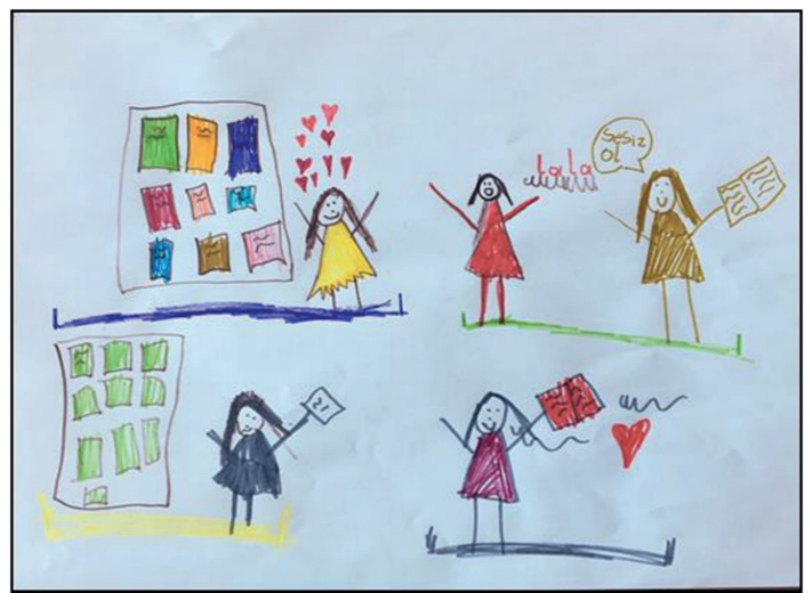

Resim 7. Şevval (1)

Kütüphane öğesi olarak 'kütüphane materyali, sistemi ve etkinlikleri' ana temalarının altında yer alan kitap, raf öğelerini; 'la la' diye gürültülü bir şekilde şarkı söyleyen arkadaşına 'Sessiz ol!' diyerek kütüphane kurallarını, elindeki kitapla da kitap okuma etkinliğini resmeden 1. sınıf öğrencisi Şevval, resimsel anlatımına dayalı yorumunda da 'kütüphanede sessiz olunması gerektiğini ve çizdiği kalplerle de kitapları çok sevdiğini’ ifade etmiştir (Resim 7). Çizdiği resme dayalı olarak Şevval'in kütüphane kurallarından haberdar ve ayrıca iyi bir kütüphane kullanıcısı olduğunu söylemek mümkündür.

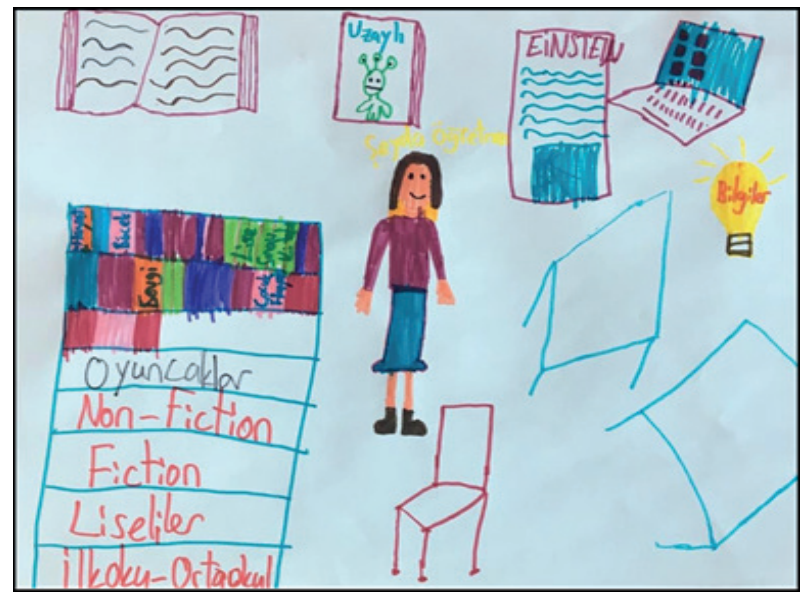

Resim 8. Berilsu (4)

Yaptı̆̆ 1 resme dayalı yorumunda 'kütüphane denilince aklıma kitapların ve yeni bilgilerin olduğu yer geliyor' diyerek, kütüphane materyali, sistemi ve personeli ana temalarını vurgulayan 
4. sınıf öğrencisi Berilsu, resimsel anlatımında ise kütüphane öğesi olarak kitap, raf, masa, sandalye, bilgisayar ve kütüphaneciyi (Şeyda öğretmeni) çizmiştir. Ayrıca nonfiction-fiction (konusal-roman) kitapları farklı raflara yerleştirerek kütüphanede bir düzenin olduğunu vurgulamış, 'kütüphane sistemi' ana temasının altında yer alan sınıflama sistemini de yansıtmıştır. Oyuncaklar bölümü yaparak da kütüphanede oyuncakların olduğunu göstermiştir (Resim 8). Berilsu'nun resminde öne çıkan mesaj ise kütüphane aracılığıyla bilgiye ulaşılabildiğidir. Resmine Çizime dayalı olarak Berilsu'nun kütüphaneyi ve kurallarını iyi bildiğini ve bu konuda temel eğitim aldığını söylemek mümkündür. Berilsu'nun kütüphaneye ve kitaba yönelik algısının kütüphaneci tarafından şekillendirildiği çizdiği resminde kütüphaneciye ve kitaplara yer vermesinden resimden anlaşılmaktadır.

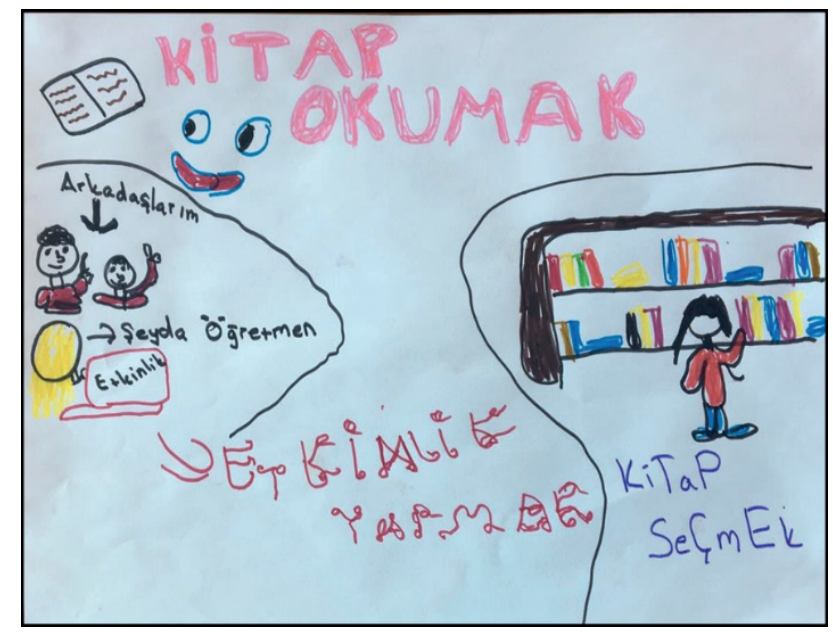

Resim 9. Efe (3)

3. sınıf öğrencisi Efe resimsel anlatımında kütüphane öğesi olarak 'kütüphane materyali, kütüphane sistemi, kütüphane etkinlikleri ve kütüphane personeli’ ana temalarının altında yer alan kitap ve rafi; kütüphanede parmak kaldırarak etkinliğe katıldığını ve kütüphane dersini, kütüphaneciyi ve ödünç alma sistemini çizmiştir. Resimsel anlatımına dayalı yorumunda da 'kütüphane denilince aklıma yapılan etkinlikler, dersler ve ev için kitap seçip ödünç alma geliyor' demiştir. Ayrıca Efe, kütüphane etkinlikleri ana temasının altında yer alan, kitap okuma eylemini de çizdiği resme yazarak bu etkinliğe de değinmiştir (Resim 9). Efe'nin resmine ve yorumuna bakıldığında temel kütüphane eğitimi aldığı ve zihninde olumlu bir kütüphane algısı oluştuğu söylenebilir. 


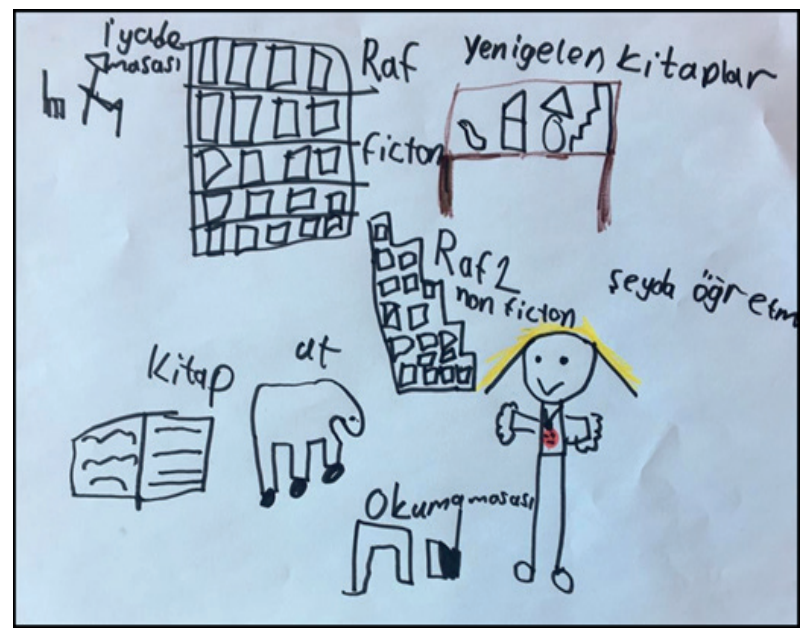

Resim 10. Melih (2)

Yaptığı resme dayalı yorumunda 'kütüphane denilince aklıma kitaplar, oyuncaklar ve kütüphaneci geliyor' diyerek, 'kütüphane materyali, sistemi, etkinlikleri ve personeli' ana temalarını vurgulayan 2. sınıf öğrencisi Melih resimsel anlatımında ise kütüphane öğesi olarak kitap, raf, oyuncak at; okuma masası çizerek kitap okuma etkinliğini, iade masası çizerek ödünç verme sistemini ve kütüphaneciyi çizmiştir. Ayrıca yaptığı resimde nonfiction-fiction (konusalroman) kitaplarını farklı raflarda çizerek kütüphanede belli bir düzenin olduğunu vurgulamış; 'kütüphane sistemi' ana temasının altında yer alan sınıflama sistemini de yansıtmıştır. Bununla birlikte resminde kütüphanenin fiziksel düzenine de vurgu yapmıştır (Resim 10). Çizime dayanarak Melih'in, kütüphane hakkında bilgi sahibi olduğu ve kütüphane ve hizmetlerine yönelik temel eğitim aldığı söylenebilir. Bu da bir okul kütüphanesinde mesleki ve akademik eğitim almış bir kütüphanecinin bulunmasının, çocukların kütüphaneye yönelik olumlu alg1 edinmelerinde ve eylemlerinde pozitif etkiye sahip olduğunu göstermektedir. 


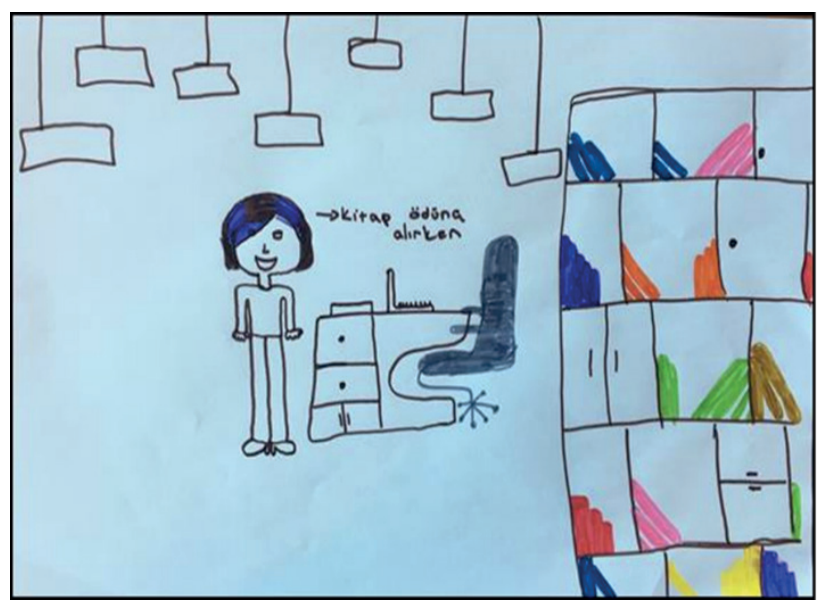

Resim 11. Yaprak (3)

Resimsel anlatımında kütüphane öğesi olarak 'kütüphane materyali ve sistemi ana temalarının altında yer alan kitap ve raf öğelerini ve kendini kitap ödünç alırken çizen ayrıca ödünç verme sistemine yer veren 3. sınıf öğrencisi Yaprak, resimsel anlatımına dayalı yorumunda da 'kütüphane denilince aklıma kitap ödünç alma geliyor' diyerek kütüphaneye bakış açısını ifade etmiştir (Resim 11). Bu da Yaprak’ın iyi bir kütüphane kullanıcısı olduğunu ve kütüphane hakkında temel eğitim aldığını göstermektedir. Bunun nedeninin okulda kütüphanenin ve kütüphanecinin bulunması ve öğrencilere temel kütüphane eğitiminin verilmesi olduğu söylenebilir.

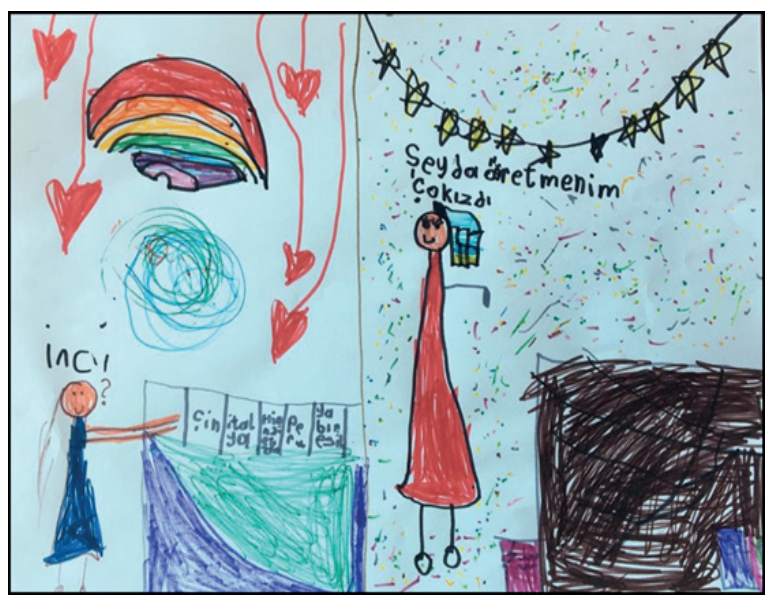

Resim 12. İnci (1) 
Resimsel anlatımında dağınık bir raf çizerek Şeyda öğretmenin rafı dağıttıkları için onları uyardığını anlatan 1. sınıf öğrencisi İnci, 'kütüphane sistemi' ana temasının altında yer alan kütüphane kurallarına, yine aynı şekilde ülkelerle ilgili kitapları aynı rafa koyarak aynı konuya ait kitapların bir arada olduğunu belirterek, 'kütüphane sistemi' ana temasının altında yer alan sınıflama sistemine değinmiştir (Resim 12). Resimsel anlatımına dayalı yorumunda da 'kütüphaneyi çok sevdiğini bunu kalplerle ve gökkuşağıyla ifade ettiğini' vurgulamıştır. Çizdiği resme dayanarak İnci'nin de diğer öğrenciler gibi temel kütüphane eğitimi aldığı, kütüphane algısının şekillenmesinde kütüphaneci rolünün etkisinin olduğu anlaşılmaktadır.

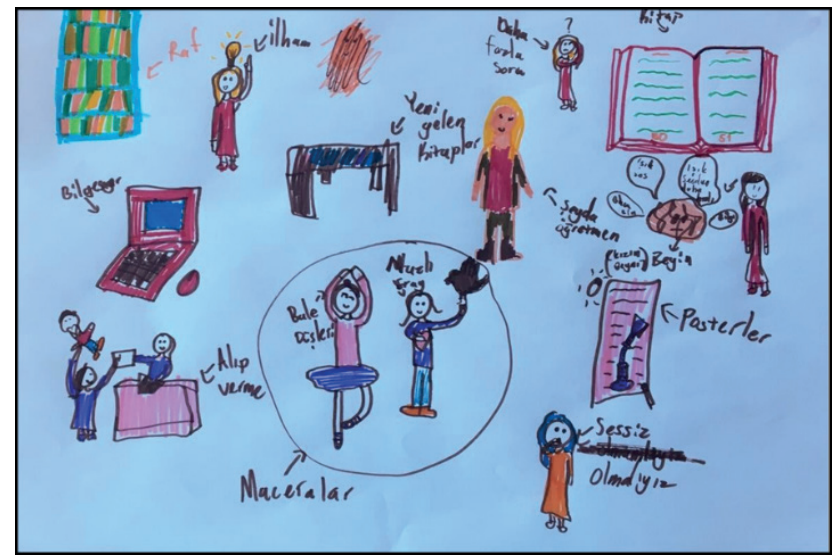

Resim 13. Nehir (4)

4. sınıf öğrencisi Nehir, yaptığı resme dayalı yorumunda 'kütüphane denilince aklıma ilham veren kitaplar, kitapların içinde yer alan kitap karakterler ile sorularımıza cevap bulabildiğimiz ve beynimizin bilgiyle dolduğu bir yer geliyor" şeklinde bir ifade kullanmıştır. Resimsel anlatımında ise 'kütüphane materyali, sistemi ve personeli' ana temalarını vurgulayan Nehir, kütüphane öğesi olarak kitap, raf, poster, bilgisayar, oyuncak; elindeki oyuncakla, kitap ödünç aldığını çizerek ödünç verme sistemini; 'sessiz olmalıyız' uyarısıyla kütüphane kurallarını ve ayrıca kütüphaneciyi göstermiştir (Resim 13). Bu durum Nehir’in diğer öğrenciler gibi temel kütüphane eğitimi aldığını ve kütüphane hakkında bilgi sahibi olduğunu göstermektedir. Bunun nedeninin okulunda kütüphane ve kütüphaneci olduğu söylenebilir. 


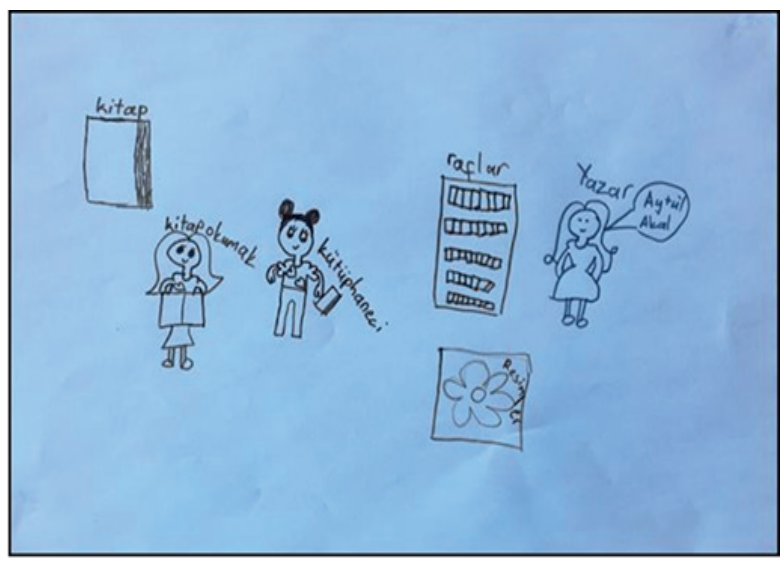

Resim 14. Ayşe Betül (2)

Resimsel anlatımında kütüphane öğesi olarak kitap, raf, poster çizerek 'kütüphane materyali' ana temasına yer veren 2. sınıf öğrencisi Ayşe Betül, 'kütüphane etkinlikleri' ana temasından kitap okuma eylemini çizerek kitap okuma etkinliğine ve ayrıca yazar Aytül Akal'ı çizerek kütüphane haftasında yapılan yazar etkinliğine değinmiştir. ‘Kütüphane personeli’ ana temasının altında yer alan kütüphaneci öğesine de yer vermiştir (Resim 14). Resimsel anlatımına dayalı yorumunda da 'kütüphanenin kitap okuma yeri olduğunu' ifade etmiştir. Yaptığı resme dayalı olarak Aytül Akal'ın kütüphane haftası hakkında bilgi sahibi olduğunu, bunun nedeninin de okuldaki kütüphanecinin söz konusu hafta hakkında etkinlikler düzenlediğini göstermektedir.

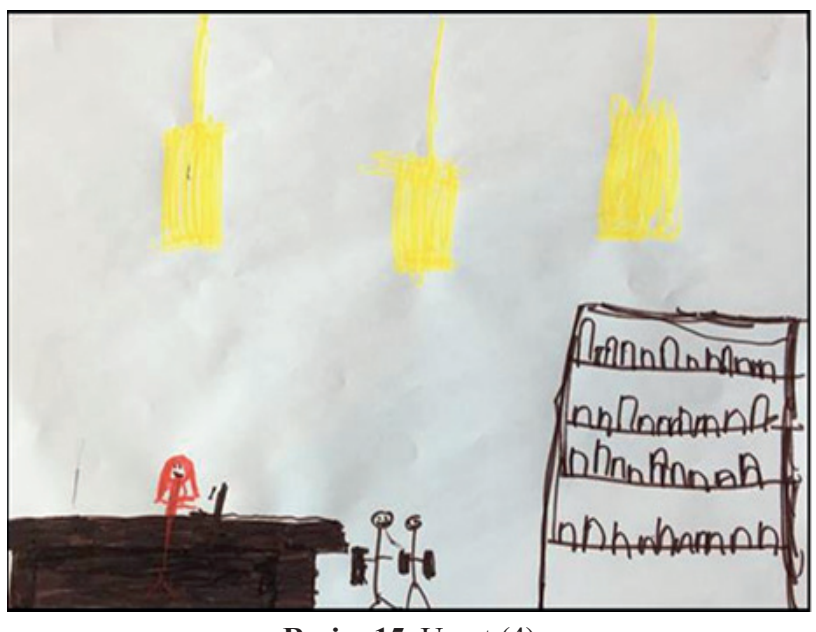

Resim 15. Umut (4) 
Resimsel anlatımda kendisini kitap ödünç alırken çizen 4. sınıf öğrencisi Umut, 'kütüphane materyali, sistemi ve personeli' ana temalarını vurgulamıştır. Kitap ve raf çizerek 'kütüphane materyali'; ödünç verme masası çizerek 'kütüphane sistemi' ve kütüphaneciyi çizerek, 'kütüphane personeli' ana temalarına dikkat çekmiştir (Resim 15). Umut resme dayalı yorumunda da 'kütüphane denilince aklıma ödünç aldığım kitaplar geliyor' diyerek kütüphaneye bakış açısını ortaya koymuştur. Umut'un kitap ve kütüphaneyi özdeşleştirdiği ve kütüphane algısını kitaplar üzerine kurduğu anlaşılmaktadır. Çizdiği resme ve yaptığı yoruma bakarak Umut'un diğer öğrenciler gibi temel kütüphane eğitimi aldığı söylenebilir.

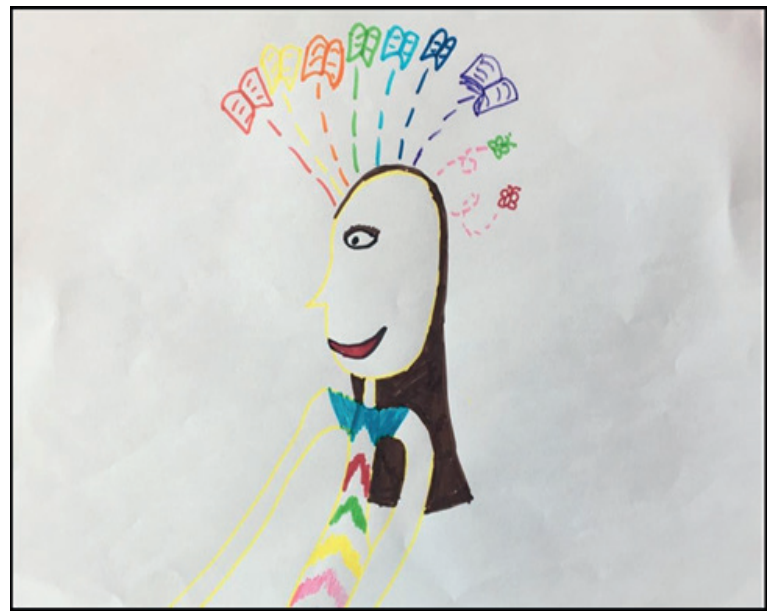

Resim 16. İpek (2)

2. sınıf öğrencisi İpek yaptığı resme dayalı yorumunda 'kütüphane denilince aklıma beynimizin farklı kitap ve bilgilerle dolduğu bir yer geliyor' demiştir. Resimsel anlatımında ise İpek, kitap ve kitap okuma eylemini resmine yansıtarak, 'kütüphane materyali' ve 'kütüphane etkinlikleri’ ana temalarına yer vermiştir (Resim 16). Çizdiği resimde İpek kitap okumanın insanı bilgili kıldığına değinmiştir.

\section{SONUÇ}

Çalışmada öğrencilerin kütüphaneye karşı yaklaşımlarını, algılarını ve kütüphane hakkında neler bildiklerini öğrenmek için resim çizdirilmiş, en açık ve en yalın şekliyle çocukların kütüphaneye yönelik kendi öz düşünceleri resimler aracılığıyla ortaya konulmaya çalışılmıştır. Öğrencilerin kütüphane hakkındaki görüşlerini görsel olarak daha iyi anlatacakları düşünülerek, resim çizdirme yöntemine başvurulmuştur. Çizmiş oldukları resimleri de bir iki cümle ile yorumlamaları istenmiştir.

Öğrencilerin çoğu resimlerinde kütüphaneyi mekânsal olarak yansıtmışlardır. Genel olarak bakıldığında öğrenciler kütüphane temasına ait alt başlıklardan kitap, raf ve kütüphaneci 
öğelerine daha çok yer vermişlerdir. 'Kütüphane Materyali' temasının altında yer alan öğelerden, öğrencilerin tamamının (\%100) kütüphane denilince akıllarına ilk gelen şeyin kitap olduğu görülmektedir. İkinci olarak da öğrencilerin 50’si (\%88) raf; üçüncü olarak da kütüphane personeli ana temasının altında yer alan kütüphaneci öğesine öğrencilerin 36’sı (\%63) yer vermişlerdir. Öğrencilerin 4’ü ise (\%7) ‘Kütüphane Etkinlikleri’ ana temasının altında yer alan kütüphane haftası etkinliklerine değinmiştir. Öğrenciler arasında kütüphane algısı bakımından cinsiyet farklılığı bulunmaktadır. Nitekim kız öğrenciler erkek öğrencilere göre kütüphaneye dair öğelerin çoğuna daha fazla yer vermişlerdir. Bazı öğrencilerin resimlerinde kütüphaneci öğesine ve kütüphane haftasına değinmelerinin en temel nedeninin, okullarında kütüphane ve kütüphaneci bulunması ve bu kütüphancinin de kütüphane eğitimi vermesi ve kütüphane haftasında çeşitli etkinlikler düzenlemesi olduğu söylenebilir.

Resimsel anlatımlarda ortaya çıkan kütüphane algısına ilişkin çizimler ve kavramlar, öğrencilerin kütüphaneye karşı algılarının ve bilgilerinin olduğunun kanıtıdır. Araştırma kapsamında öğrencilerin tamamının kütüphane öğelerinden en az birine yer vermeleri aslında öğrencilerin içinde bulundukları çevreyle ve okulla ilişkilendirilebilir; çünkü Bilkent Erzurum İlkokulu'nda her sınıfın sahip olduğu bir sınıf kütüphanesi, tüm sınıf seviyelerinin kullanabildiği bir okul kütüphanesi ve ayrıca akademik mesleki ve akademik eğitim almış kütüphaneciler mevcuttur.

Çalışmada, Erzurum ilinde bulunan Bilkent İlköğretim Okulu'nda eğitim alan 14'ü 1. sınıf, 17'si 2. sınıf, 15'i 3. sınıf ve 11'i de 4. sınıf olmak üzere toplam 57 öğrenci resim çizmiş ve çizdikleri resimleri yorumlamaları istenmiştir. Öğrenciler tarafından çizilen resimlere ve yaptıkları yorumlara dayanarak ulaşılan sonuçlar şunlardır:

- Genel olarak öğrencilerin kütüphaneye karşı tutumları benzerdir. Bu doğrultuda çizdikleri resimlerde kütüphaneyi mekânsal olarak yansıtan öğrencilerin büyük çoğunluğu kitap, raf, sandalye, masa ve oyuncak gibi kütüphane materyallerine yer vermiştir. Bu sonuç, öğrencilerin eğitim aldıkları okulda kütüphanenin bulunmasının öğrenci zihninde mekân bağlamlı bir kütüphane algısını oluşturduğunu göstermektedir.

- Öğgrencilerin büyük çoğunluğunun kütüphaneyi kitap ödünç alma, oyun oynama, kitap okuma vb. gibi etkinliklerin yürütüldüğü bir yer olarak çizdikleri görülmektedir. $\mathrm{Bu}$ da kütüphanede bu faaliyetlerin yapıldığını, çocukların eylemlerinde ve zihinlerinde bunun farkında olduklarını göstermektedir. Öğrencilerin büyük çoğunluğu resimlerinde ve anlatımlarında kütüphane materyallerine yer vermiştir. Bununla birlikte öğrenciler, 'kütüphane etkinlikleri ve sistemi' ana temalarının altında yer alan kitap okuma, kütüphane haftası kutlama ve ders çalışma gibi öğelere değinerek kütüphaneyi işlevsel bakımdan da yansıtmışlardır. Öğrencilerin kütüphane hakkında istenilen bilgiye sahip ve aktif birer kullanıcı olmalarında okullarındaki kütüphanenin ve kütüphanecinin 
etkisinin olduğu anlaşılmaktadır. Bu sonuca dayanarak okul kütüphanelerinin ve kütüphancilerin öğrencilere kütüphaneyi tanımalarında, kullanmalarında ve zihinlerinde ve eylemlerinde kütüphaneye, kitaba ve okumaya karş1 yerleşik olumlu bir alg1 oluşturmada çok önemli bir role sahip oldukları söylenebililir.

- Kütüphane denilince öğrencilerin akıllarına çoğunlukla ilk gelen şey kitap olmuştur. Nitekim bu durum çizilen resimlerle de doğrulanmıştır. Öğrencilerin kütüphaneyi kitapla ilişkiledirmeleri ve bunu resimlerinde ve yorumlarında belirtmelerinin nedeni, okullarında kütüphane bulunması olduğu söylenebilir.

- Öğrenciler resimlerinde kütüphaneciye de yer vermiştir. Nitekim öğrencilerin 32'si (\%56) kütüphaneci öğesini çizmiştir. Bu doğal bir sonuçtur, çünkü öğrencilerin eğitim aldıkları okulda düzenli bir kütüphanenin ve kütüphanecinin olması bu durumu ortaya çıkarmıştır. Nitekim bu sonuçtan okul kütüphanelerinin, öğrencinin zihninde kütüphane ile birlikte kütüphaneci olgusunun oluşmasında çok önemli bir rol üstlendiği çıkarılabilir. Bu açıdan okullarda etkin bir okul kütüphanesinin varlığı, hem öğrenci başarısına hem de öğrencide olumlu bir kütüphane ve kütüphanci algısı oluşmasına neden olacaktır.

- Öğrencilerin çizdikleri resimler, sınıf düzeyine göre değişiklik göstermiştir. Örneğin, üst sınıflar alt sınıflara göre kütüphane algısını daha iyi çizerek ifade etmiştir. Bazı resimlerde, 1. sınıfların resimlere yansıttıkları birçok öğeye, 4. sınıflar değinmemiştir. Örneğin, 2. sınıflar, 3. sınıflara göre kütüphaneyi işlevsel olarak daha iyi yansıtmışlardır. Bu durum kütüphane algısının, yaşla veya sınıf düzeyiyle bir ilişkisi olmadığını göstermektedir. Bunun en önemli nedeni öğrencilerin 6-10 yaş arası şematik öncesi aşama ve şematik aşama düzeylerinde yer almalarıdır. Bu da doğal olarak algı değişimi ile birlikte resimleme ve yorumlama farkını beraberinde getirmiştir.

- $\quad$ Eğer bir okulda kütüphane ve kütüphaneci varsa öğrencilerin kütüphaneye bakış açısının tamamen değiştiğini öğrenci çizimlerinden anlamak mümkündür. Nitekim Bilkent Erzurum İlkokulu'nda hem kütüphanenin hem de kütüphanecinin olması öğrencilerin çizimlerinde etkisini göstermiştir. Ayrıca öğrencilerin kütüphaneyi sürekli kullanmalarının teşvik edilmesi ve öğrencilerle kütüphanede yapılan dersler, öğrencilerde olumlu etkiler oluşturarak kütüphaneyle ilgili ödünç verme ve sinıflama sistemi gibi etkinlikler resimlerine yansımıştır.

- Öğrencilerin çizimlerinde kütüphanede yer alan masa, sandalye, raf, kitap, kütüphaneci, lamba vb. gibi objelere yer verdikleri; ayrıca büyük çoğunluğunun ise kitap ve rafa vurgu yaptıklarını ve bu nesneleri öne çıkardıkları görülmektedir. 
Hakem Değerlendirmesi: Dı̧̧ bağımsız.

Yazar Katkıları: Çalışma Konsepti/Tasarım- Ş.Ç.E., M.Y.; Veri Toplama- Ş.Ç.E., M.Y.; Veri Analizi/Yorumlama- Ş.Ç.E., M.Y.; Yazı Taslağı- Ş.Ç.E., M.Y.; İçeriğin Eleştirel İncelemesi- Ş.Ç.E., M.Y.; Son Onay ve Sorumluluk- Ş.Ç.E., M.Y.

Çıkar Çatışması: Yazarlar çıkar çatışması bildirmemiştir.

Finansal Destek: Yazarlar bu çalışma için finansal destek almadığını beyan etmiştir.

Peer-review: Externally peer-reviewed.

Author Contributions: Conception/Design of Study- Ş.Ç.E., M.Y.; Data Acquisition- Ş.Ç.E., M.Y.; Data Analysis/ Interpretation- Ş.Ç.E., M.Y.; Drafting Manuscript- Ş.Ç.E., M.Y.; Critical Revision of Manuscript- Ş.Ç.E., M.Y.;Final Approval and Accountability- Ş.Ç.E., M.Y.

Conflict of Interest: The authors have no conflict of interest to declare.

Grant Support: The authors declared that this study has received no financial support.

\section{Kaynakça/References}

Aykaç, N. (2012). İlköğretim öğrencilerinin resimlerinde öğretmen ve öğrenme süreci algısı. Eğitim ve Bilim, 164(37), 299-315.

Cevizbaş, S. (2003). Türkiye’de özel okul kütüphanelerinin sorunları: özel okul kütüphanelerine yönelik anket. Türk Kütüphaneciliği, 17(4), 386-396.

Creswell, J. W. (2007). Qualitative inquiry and research design: Choosing among five approaches (2. bs.). Thousand Oaks, London ve New Delhi: SAGE Publications.

Creswell, J. W. (2014). Research design: Qualitative, quantitative, and mixed methods approaches (4. bs.). Thousand Oaks ve London: SAGE Publications.

Erişti, S. D. (2015). Art-based educational research to generate a practice based approach. Anadolu Journal of Educational Sciences International, Art Education Special Issue, 383-401.

Erişti, S. D. ve Belet Ş. D. (2010). İlköğretim öğrencilerinin yazılı anlatım ve resimlerinde kültür algıları. Elektronik Sosyal Bilimler Dergisi, 33(9), 245-264.

Ersoy, A. ve Türkkan, B. (2009). Perceptions about internet in elementary school children's drawings. Elementary Education Online, 8(1), 57-73.

Okyay, L. ve Fazlığlu Y., (2009). 6 yaş grubu çocukların aile resimlerinin incelenmesi. Uluslararası 5. Balkan Eğitim ve Bilim Kongresi Tam Metin Kitabı, 2(2), 672-675.

Önal, İ. ve Alaca, E. (2015). Okul kütüphanesi kullanımında öğretmenlerin rolü ve sorumlulukları. Bilgi Dünyast, 16(1), 105-126.

Padgett, D. K. (2008). Qualitative methods in social work research (2. bs.). Los Angeles: SAGE.

Salome, R. A. ve Moore, B. A (2021). Five stages of development in children's Art. Retrieved from http://my.ilstu. edu/ eostewa/ART309/Five_Stages.htm\#: :text=The $\% 20$ pre $\% 2$ Dschematic $\% 20$ stage $\% 20$ refers,to $\% 20$ $7 \% 20$ years $\% 20$ of $\% 20$ age

Yılmaz, B. (2002). Ankara'da ilköğretim öğretmenlerinin okuma ve halk kütüphanesi kullanma alışkanlıkları üzerine bir araştırma. Türk Kütüphaneciliği, 16(4), 441-460.

Y1lmaz, E. (2015). Eğitimde okul kütüphaneleri: Türkiye'de durum. Milli Eğitim Dergisi, 208, 259-286. 